\title{
Long term safety, efficacy and clinical outcomes of transobturator tension free tape (inside-out technique) in women with stress urinary incontinence
}

\author{
Poornima Penmetsa ${ }^{1}$, Indira Guntoory ${ }^{1 *}$, Ravi K. Raju Namburi ${ }^{2}$, Jayalaxmi M. ${ }^{1}$
}

\begin{abstract}
${ }^{1}$ Department of Obstetrics and Gynecology, ${ }^{2}$ Department of Urology, MIMS, Nellimerla, Vizianagaram district, Andhra Pradesh, India
\end{abstract}

Received: 13 December 2017

Accepted: 08 January 2018

\author{
*Correspondence: \\ Dr. Indira Guntoory, \\ E-mail: indiraprasadg@gmail.com
}

Copyright: (c) the author(s), publisher and licensee Medip Academy. This is an open-access article distributed under the terms of the Creative Commons Attribution Non-Commercial License, which permits unrestricted non-commercial use, distribution, and reproduction in any medium, provided the original work is properly cited.

\begin{abstract}
Background: Stress urinary incontinence (SUI) is commonly encountered in Gynaecological practice. The management of stress urinary incontinence underwent a paradigm shift with focus changing from bladder neck suspension to support of mid urethra in the last two decades. The aim of our study is to know the safety, efficacy, subjective and objective outcomes of Transobturator Tension Free Tape (TOT) (in-out technique) in women with Stress urinary incontinence.

Methods: This is a prospective study conducted in the departments of Gynaecology and Urology at Maharajah's Institute of Medical Sciences, Nellimerla, Vizianagaram district, Andhra Pradesh, India. 62 patients were treated with Tension Free Trans-obturator tape with inside-out technique using polypropylene mesh. This study was conducted from June 2012 to May 2014. These women were followed up annually for a period of 3 years af-ter surgery. 3 year subjective and objective outcomes were assessed. Subjective outcome is defined as no loss or leak of urine on physical activity and objective outcome is defined as negative Pad test.

Results: The subjective and objective cure rates were $91.93 \%$ and $95.16 \%$ respectively.

Conclusions: Transobturator Tension free Tape is an effective treatment for Stress urinary in-continence in women providing high subjective and objective efficacy upto 3 years after surgery.
\end{abstract}

Keywords: Stress urinary incontinence, Transobturator tension free tape, Urinary leak, Urinary retention

\section{INTRODUCTION}

Stress Urinary incontinence (SUI) is the complaint of involuntary loss of urine with physical exertion (i.e. walking, straining, exercise), with sneezing, coughing or other activities raising intraabdominal pressure. ${ }^{1}$ Overall urinary incontinence has a prevalence of $25 \%-40 \%$, of which SUI accounts for $50 \%$ of cases.

The economic, social and emotional burden of urinary incontinence pro-foundly impacts patients' lives and hence mandates the treatment of Stress urinary incontinence.

Patients with SUI may benefit variably from conservative measures using pelvic floor muscle exercises, biofeedback, electrical stimulation and pharmacotherapy. Urethral bulking injection therapy can provide an intermediate option between non-surgical and surgical therapies, but surgery remains the mainstay of treatment for SUI. Although needle suspensions remain only as a point of historic discussion, retropubic suspensions have 
persisted as a reasonable treatment option for SUI. However, slings, using a variety of materials, insertion approaches and anchoring techniques, have effectively become the standard options for women with SUI.

Petros and Ulmsten (1990) proposed "Integral Theory" of SUI which pin-points the site of maximal continence zone in the mid urethra at the pubourethral ligaments, suburethral vaginal hammocks and pubococcygeus muscle. ${ }^{2}$ Urethral slings are currently the procedure of choice for surgical correction of female SUI. In 1998, Ulmsten and colleagues described the Transvaginal Tape (TVT) proce-dure.

In 2001, Delorme described the first Transobturator procedure, which did not violate the retropubic space that lies in close proximity to bladder and there-fore decreased the risk of bladder injury. ${ }^{3,4}$ In 2003, de leval developed INSIDE-OUT technique with comparable results of Delorme's OUTSIDE-IN technique. ${ }^{5}$

As with retropubic synthetic slings, this is a minimally invasive midurethral sling using a synthetic tape; specially designed needles are passed from vagina to inner groin. When performed in an appropriate fashion, the needle and subse-quently the sling pass through vaginal incision, Obturator internus, Obturator membrane, Obturator externus, Adductor brevis, gracilis tendon, subcutaneous fat and skin incision.

Patients with transobturator tape (TOT) slings demonstrate similar rates of cure compared with retropubic slings, with fewer bladder perforations and post-operative irritative voiding symptoms with almost elimination of catastrophic bowel and major vessel injury. The trade off is that the patients experience more complications referable to groin such as pain and leg weakness or numbness.

The aim of present study is to assess the safety and outcomes of inside-out technique for Stress urinary incontinence on follow-up for 3 years.

\section{METHODS}

This is a prospective study conducted in a tertiary level referral hospital, Maharajah's Institute of Medical Sciences, Vizianagaram district, Andhra Pradesh. This study was conducted after ethics committee approval, for a period of 3 years from June 2012 to May 2014 in the departments of Gynaecology and Urology.

62 Patients were treated with de leval's Inside-Out TOT Technique using a mesh of $30 \times 2 \mathrm{cms}$ with pores of greater than $75 \mu \mathrm{m}$ with loosely woven strands of polypropylene (AMID'S Classification for synthetic materials - Type I). ${ }^{6}$

Demographic information of all patients was obtained. Thorough history and physical examination was done in all patients. SUI was diagnosed on the basis of demonstrable leak on straining or coughing, Positive Bonney's test, with no post-void residue on ultrasound and no signs of outlet obstruction on Cystoscopy.

Table 1: AMID'S classification for synthetic materials.

\begin{tabular}{|c|c|c|}
\hline Туре & Description & Brands \\
\hline I & $\begin{array}{l}\text { Pove Size }>75 \mu \mathrm{m} . \\
\text { Macroporous }\end{array}$ & Trelex, Marlex. \\
\hline II & $\begin{array}{l}\text { Pore size }<10 \mu \mathrm{m} . \\
\text { Microporous }\end{array}$ & Gore - Tex \\
\hline III & $\begin{array}{l}\text { Macroporous with } \\
\text { Multifilments } \\
\text { or Microporous } \\
\text { Components }\end{array}$ & $\begin{array}{l}\text { Teflon, Tersilene } \\
\text { (Beaded Dacron } \\
\text { Mesh) }\end{array}$ \\
\hline IV & Submicronic pore size & Silastic \\
\hline
\end{tabular}

Evaluation for occult SUI was performed with the anterior wall supported as SUI can be masked if significant prolapse kinks the urethra and outlet. Urethral mobili-ty and position was assessed at rest and with straining and coughing.

The Q-tip test was done to evaluate urethral mobility. Hyper mobility was defined as Q-tip angle of more than 30 degrees from horizontal. Urodynamic studies were done as per American Urological Association (AUA) guidelines when indicated. SUI was graded by Ferrari et al classification. ${ }^{7}$

Table 2: Pre-operative subjective assessment of stress urinary incontinence.

\begin{tabular}{|ll|}
\hline Grade of SUI & $\begin{array}{l}\text { Symptoms } \\
\text { Involuntary loss of urine with sudden } \\
\text { increase in intra-abdominal presure } \\
\text { such as coughing or straining. }\end{array}$ \\
II & $\begin{array}{l}\text { Involuntary loss of urine with lesser } \\
\text { degrees of stress such as walking or } \\
\text { standing up. }\end{array}$ \\
\hline III & $\begin{array}{l}\text { Involuntary loss of urine without any } \\
\text { relation to physical activity or } \\
\text { position for example lying on bed. }\end{array}$ \\
\hline
\end{tabular}

Patients with Urge or Mixed Urinary incontinence, high grade Pelvic organ Pro-lapse (>grade 2), more than $50 \mathrm{ml}$ of post void residue, suspected neurogenic bladder, evidence of dysfunctional voiding, prior lower urinary tract surgery including anti-incontinence surgery and abnormal urinalysis were excluded.

Contraindications for the procedure include pregnancy, groin abscesses, chronic infection or pain and active anticoagulation.

All patients were counseled about the permanent nature of surgery and complications. All the procedures were done by a single surgeon. 


\section{Surgical technique}

- Pre-operative considerations- Sterile urine is confirmed before the procedure. Single dose intravenous antibiotic is given for skin and vaginal flora coverage, usually Cephalosporins and Fluoroquinolones.

- Anaesthesia and position- Under Spinal Anaesthesia with patient positioned in dorsal lithotomy position with 70 degrees flexion at hip.

- Exit site of the needle- Stab incisions given $2 \mathrm{~cm}$ superior to horizontal line level with urethra and 2 $\mathrm{cm}$ lateral to labial folds which will be exit point for helical passer.

- Vaginal incision and dissection- Anterior retraction of vaginal mucosa with Al-lis clamp and anterior vaginal incision under the mid-urethra after hydrodissec-tion of vaginal mucosa with saline or with Epinephrine and Lidocaine. The dis-section should be done upto inferior pubic ramus.

- Trocar passage- Helical passer should pass from vaginal incision to exit site hugging the inferior pubic rami to prevent injury to Obturator vessels and nerve. The vaginal sulcus is inspected to ensure that no perforation or mucosal damage has occurred.

- Cystourethroscopy- Cystoscopy was done at the end of procedure to ensure no injury to urethra or bladder.

- Tensioning- The sling should lay flat against the urethra and tension adjusted over a right angled clamp.

- Closure- Vaginal wound is copiously irrigated and closed with absorbable 3-0 polyglycolic acid suture in a running fashion. Groin stab wounds are also closed with same suture.

Any significant intra operative bleeding was noted.

Patients were re-assessed at the end of 1 month for any urinary leak and subsequently at 1 year and 3 years of follow-up. Subjective assessment for urinary leak, urgency, voiding difficulties, urinary retention and objective assessment was done using Pad Test. Ultrasound for post-void residue and physical examination for mesh exposure.

Patients with no leak were considered cured. Follow-up stopped after 3 years if there were no significant problems.

\section{RESULTS}

A total of 62 patients underwent TOT repair between June 2012 and May 2014. The median age of the patients is 38.63 years (range 30-54 years) with a median Body Mass Index (BMI) of 24.48 and mean parity of the patient is 2.82 .
On removal of catheter on first post-operative day, no patient developed SUI, 1 patient developed Grade-I SUI which resolved after re-catheterisation for 1 week.

The objective characteristics and subjective outcomes/cure rates at the time of discharge are shown in Table 3.

Table 3: Operative characteristics and subjective out comes or cure rates at the time of discharge.

\begin{tabular}{ll}
\hline Operative characteristics & \\
Mean operative time (min) \pm SD & $22.49 \pm 2.86$ \\
Mean hospital stay (day) \pm SD & $1.86 \pm 0.72$ \\
Mean follow-up (month) \pm SD & $30.42 \pm 5.68$ \\
\hline Subjective cure rates /outcomes & \\
Cured & $91.9 \%$ \\
Improved & $6.48 \%$ \\
Persistent & $1.62 \%$
\end{tabular}

Subjective and objective outcomes at 1 year and 3 years of follow - up are shown in Table 4.

Table 4: Subjective and objective outcomes at 1 year and 3 years of follow up.

\begin{tabular}{|lll|}
\hline Outcomes & Follow up & \\
\hline Subjective & 1 year & 3 years \\
\hline Cured & $54(87.09 \%)$ & $57(91.93 \%)$ \\
\hline Improved & $7(11.29 \%)$ & $4(6.45 \%)$ \\
\hline Worse/no improvement & $1(1.62 \%)$ & $1(1.62 \%)$ \\
\hline Objective & 1 year & 3 years \\
\hline No SUI & $56(90.32 \%)$ & $59(95.16 \%)$ \\
\hline Mild SUI & $5(8.06 \%)$ & $2(3.22 \%)$ \\
\hline Modeate-severe SUI & $1(1.62 \%)$ & $1(1.62 \%)$ \\
\hline Post void residue & $0-50$ & $0-70$ \\
& $($ median 12.5$)$ & $($ median 10.5$)$ \\
\hline
\end{tabular}

No significant intra operative blood loss has occurred in any case. No bladder injury or bowel injury or vascular injuries were reported 8.9. No Obturator nerve injury was reported in our study. One patient had voiding dysfunction at 1 year of follow-up (1.62\%) and she was treated with cutting of mesh (at 18 months). One patient had vaginal mesh exposure at 1 month and was managed conservatively.

Complications of the procedure are shown in Table 5.

Table 5: Complications of the procedure.

\begin{tabular}{|ll|}
\hline & Total patients (62) \\
\hline Complications & Number (percentage) \\
\hline Voiding dysfunction & $1(1.62 \%)$ \\
\hline Mesh exposure & $1(1.62 \%)$ \\
\hline Groin pain & $2(3.24 \%)$ \\
\hline
\end{tabular}


The Patient Global Impression of Improvement (PGI-I) Score was evaluat-ed on post-operative discharge and 3 months follow-up. The score was evaluated with respect to the pre-operative condition at each follow-up. At discharge 60 pa-tients were completely satisfied and 2 patients were not happy. 1 due to groin pain and 1 due to voiding dysfunction. All were completely satisfied at 1 year of follow-up.

PGI-I Score (Patient Global Impression of Improvement) Score is shown in Table 6.

Table 6: PGI-I (Patient Global Impression of Improvement) score.

\begin{tabular}{|llll|}
\hline Score & Discharge & 1 year & 3 years \\
\hline Completely satisfied & 60 & 62 & 62 \\
\hline Better & 2 & nil & Nil \\
\hline
\end{tabular}

\section{DISCUSSION}

The ultimate goal of SUI management is to achieve perfect continence with minimal morbidity. Proper evaluation of pelvic floor anatomy and function should maximise the probability of outcomes. Transobturator tape (TOT) repair has proven to be safe and highly effective. Initial surgeries for SUI were aimed to lift and support Vesico-Urethral junction, but recently due to Integral Theory of Delancy, the emphasis has been shifted to supporting of mid-urethra. ${ }^{8}$

Although retropubic TVT gained much popularity with good results initially, it has been associated with a number of pre and post-operative complications including mesh erosion, acute urinary retention (AUR), post-op Over Active Bladder (OAB), Vascular and bladder injuries. ${ }^{9,10}$ These are mainly due to blind upward vaginal passage of trocars in retropubic space. ${ }^{11,12}$

To reduce the complications associated with blind passage of trocars in retropubic space, Delorme et al described the Trans obturator approach. Later de Leval described Inside-out technique of passing the tape obviating any complication. We have done 62 cases of Genuine Stress Incontinence using Inside-out technique as described by de Leval.

Table 7: Comparison of cure rates of present study with other studies.

\begin{tabular}{|llllll|}
\hline Name of study & Number of patients & Type of mesh & Follow up & Cured (\%) & Assessment \\
\hline Present study & 62 & gynaecare tvt & 36 months & 91.9 & Stress test, pad test \\
\hline Zuilo et al & 37 & gynaecare tvt-o & 12 months & 89 & Urodynamics \\
\hline Rinne et al & 131 & gynaecare tvt & 12 months & 93.1 & Stress test, pad test \\
\hline Hinoul et al & 85 & gynaecare tvt & 12 months & 96.4 & Stress test, pad test \\
Tincello et al & 238 & gynaecare tvt & 12 months & 97.6 & Stress test \\
\hline
\end{tabular}

Cure rates of our study are compared with other studies and tabulated in Table 7.

Voiding disturbances were reported in Urethral Surgeries. ${ }^{13-15}$ One was seen in present study. This is probably due to increased tension on the tape, similar observation was made by Romero et al. ${ }^{16}$ One (1.62\%) patient had increased (PVRU) Post void residual urine on USG which is similar to that reported by Romero et al (3\%) and by Bozkurt et al (3.2\%). ${ }^{16,17}$ No cases of de novo urgency were reported in our study. Voiding dysfunction with transobturator approach is $2.0 \%$ in the TOMUS trial. ${ }^{18}$ Pre-operative urodynamic variables have been evaluated to assess their predictive value in postoperative voiding dysfunction. ${ }^{19-22}$

The risk of bladder injury is considerably lower, less than $1 \%$ with the transobturator approach, but it does exist and hence Cystoscopy should be considered in TOT procedures as well. ${ }^{23}$ The risk of urethral perforation with needle passage in transobturator space is $0.1-2.5 \% .{ }^{24-26} \mathrm{In}$ the presence of a urethral injury, sling placement is contraindicated, and the procedure can be undertaken after 6 weeks. ${ }^{27}$

Bleeding with mid-urethral sling can occur either during the vaginal dissection or with needle passage and perforation of the transobturator space. The risk of bleeding in TOT is around $1 \%$.

Mesh exposure is another common complication, but it had presented in only one case in our study (1.62\%), which was managed conservatively. Mesh extrusion of tape appears to be increased with the transobturator approach and is more likely to occur at the lateral vaginal sulci. $^{28,29}$ The management is conservative with observation, but rarely partial or total removal of sling may be necessary. ${ }^{30}$

The exact cause of these complications is debatable but they are likely to arise from a combination of patient and technical factors. These include patient body habitus, sub clinical infection, poor tissue in-growth into the sling, disturbed wound healing, rolling and twisting of sling, excessive friction between host tissue and sling, 
iatrogenic injury and technical error. Biochemical properties of sling have shown to play a major role in the incidence of complications related to mesh exposure. Increased pore size allows excellent tissue in-growth and promotes interaction with host tissue and decrease encapsulation and infection. Adherence to meticulous surgical technique and use of poly propylene mesh with favourable mechanical properties should help to minimise complications.

The patient satisfaction following surgery is extremely good and patients are very much satisfied with the outcome of the surgery. Patient perception of relief of symptoms studied using the subjective PGI-I score indicates that mid-urethral sling surgery is able to achieve a high level of patient satisfaction.

Morey et al stated that the position of the Transobturator Tape replaces the damaged pubourethral ligament with a permanent mesh tape that provides the support needed to prevent leakage. The angle of the TOT Tape is much less acute than TVT. Therefore, not only is this more anatomic and natural, it also causes fewer problems with urinary dysfunction and obstruction.

\section{CONCLUSION}

The Transobturator Tape (TOT) surgery by INSIDEOUT technique is safe and easy to perform. It has relatively low complication rate and better outcome in the long term.

Funding: No funding sources Conflict of interest: None declared

Ethical approval: The study was approved by the Institutional Ethics Committee

\section{REFERENCES}

1. Abrams P, Cardozo L, Fall M, Griffiths D, Rosier P, Ulmsten $U$, et al. The standardization of Terminology of Lower Urinary Tract infection: report from the standardization sub-committee of the International continence Society. Neurourol Urodyn. 2002;21(2):167-78.

2. Petras PE, Ulmsten UI. An integral theory of female urinary incontinence: ex-perimental and clinical conditions. Acta obslet Gynecol Scand Suppl. 1990;153:7-31.

3. Delorme E. Transobturator urethral suspension. mini - invasive procedure in the treatment of stress urinary incontinence in women. Prog Urol. 2001;11:1306-13.

4. Delorme E. Droupy S, de Tayrac R, Delmas V. Transobturater Tape (Uratape): A new minimally invasive procedure to treat female urinary incontinence. Eur Urol. 2004;45:203-7.

5. de level J. Novel surgical technique for the treatment of female stress urinary incontinence: Transobturator Vaginal Tape inside-out. Eur Urol. 2003;44:724-30.
6. Amid PK. Classification of biomaterials and their related complications in ab-dominal wall hernia Surgery. Hernia. 1997;1:15-21.

7. Ferrari A, Bavesi L, Frigerio L, Costa M. A grading Model for stress urinary incontinence. Urology. 1986;27:76-8.

8. Delancy JO. Anatomical aspect of vaginal eversion after hysterectomy. Am Obstet Gynecol. 1992;166(6 pt 1):1717-24.

9. Peyrat L, Boutin JM, Broyere F, Haillot O, Farfak H, Lanson Y. Intestinal perforation as a complication of Tension free vaginal tape procedure for urinary incontinence. Eur Urol. 2001;39:603-5.

10. Hermieu JF, Messas A, Delmas V, Ravery V, Dumonceau O, Boccon-Gibod L. Bladder injury after TVT Transobturator (article in French). Prog Urol 2003;13:115-7.

11. Delorme E. Transobutator urethral suspension; mini invasive procedure in the treatment of stress urinary incontinence in women (Article in French) Prog Urol. 2001;11:1306-13.

12. Barber MD, Kleemen S, Karram MM, Paranso MF, Walters MD, Vasadeva S, et al. transoburator tape compared which trans vaginal tape for the treatment of stress urinary incontinence a randomised control trail. Obstet Gynaecol. 2008;111:611-2.

13. Deng DY, Rutman M, Raz S, Rodriguez LV. Presentation and management of major complications of midurethral slings. Are complications under-reported? Neurourol Urodyn. 2007;26:46-52.

14. Niti VW. Complicaitons of midurethral slings and their management. Can Urol Assoc J. 2012;6(5Suppl 2):S120-2.

15. Bullock TL. Ghoniem G Klutke CG, Staskin Dr. Advances in female stress urinary incontinence: mid urethral slings. BJU Int. 2006;98Suppl 1:32-40.

16. Romero-Nava LE, Gomez-Cardoso R. Stress urinary incontinence treatment with modified technique tension-free vaginal tape obturator. Gynecol Obstet Mex. 2015;83:537-44.

17. Bozkurt M, Yumru AE, Salman S. Assessment of preoperative early and late postoperative complications of the inside-out transobturator tape procedure in the treatment of stress urinary incontinence Can. Exp Obstet Gynecol. 2015;42:829.

18. Brubaker L, Norton P, Albo M, Chai T, Dandreo K, Lloyd K, Lowder J. Ad-verse events over two years after retropubic or transobturator midurethral sling surgery : findings from the Trial of Midurethral Sling (TOMUS) Study. Am J Obstet Gynecol. 2011;205(5):498.e1-6.

19. Wang KH, Neimark M, Davila GW. Voiding dysfunction following TVT procedure. Int Urogynecol J Pelvic Floor Dysfunct. 2002;13:353-7.

20. Hong B, Park S, Kim HS, Choo MS. Factors predictive of Urinary retention after a tension-free vaginal tape procedure for female stress urinary incontinence. J Urol. 2003;170(3):852-6. 
21. Klutke C, Siegel S, Carlin B, Paszkiewicz E, Kirkemo A, Klutke J. Urinary retention after tensionfree vaginal tape procedure: incidence and treatment. Urology. 2001 Nov 30;58(5):697-701.

22. Norton PA, Nager CW, Chai TC, Mueller E, Stoddard A, Lowder J, et al. Risk factors for incomplete bladder emptying after midurethral sling. Urology. 2013;82(5):1038-43.

23. Tamussino K, Hanzal E, Kolle D, Tammaa A, Preyer $\mathrm{O}$, Umek W, et al. Transobturator tapes for stress urinary incontinence: results of the Austrain registry. Am J Obstet Gynecol. 2007;197(634):e1-5.

24. Kuuva N, Nilsson CG. A nationwide analysis of complications associated with the tension-free vaginal tape (TVT) procedure. Acta Obstet Gynecol Scand. 2002;81:72-7.

25. Collinet P, Ciofu C, Costa P, Cosson M, Deval B, Grise $\mathrm{P}$, et al. The safety of the inside-out transobturator approach for transvaginal tape (TVTO) treatment in stress urinary incontinence: French registry data on 984 women. Int Urogynecol J Pelvic Floor Dysfunct. 2008;19:711-5.

26. Gold RS, Groutz A, Pauzner D, Lessing J, Gordon D. Bladder perforation during tension-free vaginal tape Surgery: does it matter? J Reprod Med. 2007;52:616-8.

27. Dmochowski RR, Blaivas JM, Gormley EA, Juma S, Karram MM, Lightner DJ, et al. Update of AUA guide-lineon the surgical management of female stress urinary incontinence. J Urol. 2010;193:190614.

28. Latthe PM, Foon R, Toozs-Hobson P. Transobturator and retropubic tape pro-cedures in stress urinary incontinence: a systematic review and meta-analysis of effectiveness and complications. BJOG. 2007;114:522-31.

29. Novara G, Artibani W, Barber MD. Updated systematic review and meta-analysis of the comparative date on colposuspensions, pubovaginal slings, and midurethral tapes in the surgical treatment of female stress urinary incontinence. Eur Urol. 2010;58:218-38.

30. Kobashi KC, Govier FE. Management of vaginal erosion of polypropylene mesh slings. J Urol. 2003;169:2242-3.

Cite this article as: Penmetsa $\mathrm{P}$, Guntoory I, Namburi RKR, Jayalaxmi M. Long term safety, efficacy and clinical outcomes of transobturator tension free tape (inside-out technique) in women with stress urinary incontinence. Int J Reprod Contracept Obstet Gynecol 2018;7:442-7. 